Kumar, G., Shukla, A., Chhoker, A., \& Thapa, R. K. (2021). Identification of Factors Determining Winning in Men's and Women's Beach Volleyball: a Logistical Regression Approach. Teoriâ ta Metodika Fizičnogo Vihovannâ, 21(1), 26-35.

https://doi.org/10.17309/tmfv.2021.1.04

ISSN 1993-7989 (print). ISSN 1993-7997 (online)

\title{
IDENTIFICATION OF FACTORS DETERMINING WINNING IN MEN'S AND WOMEN'S BEACH VOLLEYBALL: A LOGISTICAL REGRESSION APPROACH
}

\author{
Gopal Kumar ${ }^{\mathrm{ABCD}}$, Anshuman Shukla ${ }^{2 \mathrm{AB}}$, Amit Chhoker ${ }^{2 \mathrm{AB}}$, Rohit Kumar Thapa ${ }^{1 \mathrm{ACD}}$ \\ ${ }^{1}$ Lakshmibai National Institute of Physical Education \\ ${ }^{2}$ Indira Gandhi Institute of Physical Education and Sports Sciences \\ Authors' Contribution: A - Study design; B - Data collection; C - Statistical analysis; D - Manuscript Preparation; E - Funds Collection
}

Corresponding Author: Rohit Kumar Thapa, E-mail: rohitthapa04@gmail.com

Accepted for Publication: March 20, 2021

Published: March 25, 2021

DOI: $10.17309 /$ tmfv.2021.1.04

\begin{abstract}
The purpose of this study was to find the factors responsible for winning in the men's and women's beach volleyball championship.

Materials and methods. The study sample consisted of a total of 212 matches for men and 214 matches for women of the 2017 \& 2019 FIVB Men and Women Beach Volleyball World Championships held at Vienna \& Hamburg from 28 July to 6 Aug 2017 and 28 June to 7 July 2019. The matches were played by 192 teams (both men and women combined) consisting of 384 numbers (both men and women combined) of players from different nations. The data were analyzed using Binary Logistic Regression (Forward: LR Method) with the result of the game as the dependent variable and predictor variables as covariates. $\beta$, standard error $\beta$, Wald's $\chi^{2}$, odds ratio with $95 \%$ confidence interval were calculated. Model evaluation was conducted using the likelihood ratio test, Cox \& Snell $\left(\mathrm{R}^{2}\right)$, and Nagelkerke $\left(\mathrm{R}^{2}\right)$ tests. The goodness of fit test for the models was conducted using the Hosmer \& Lemeshow test.

Results. The analysis revealed seven factors related to winning in men's and women's competition. While in league rounds, six factors in men's and seven factors in women's competition were related to winning. Besides, in knockout rounds, four factors in men's and six factors in women's competition were related to winning.

Conclusion. The study shows that there is a significant association of important factors with respect to winning a match in an elite beach volleyball championship. The coaches and players can take note of the important factors responsible for winning in the elite beach volleyball championship, with different factors playing an important role in men's and women's competition during league and knockout rounds as well.
\end{abstract}

Keywords: notational analysis, chances, FIVB, prediction, world championship, skill.

\section{Introduction}

Beach volleyball has developed from a recreational activity to a professional sport over the last few decades. Since its inclusion in the Olympics in the 1996 Atlanta Summer Olympic Games, the game has shown tremendous growth in popularity all over the world. Beach volleyball is an intermittent sport played by teams of two players in a sand court and demanding powerful short rallies interspersed by pauses or less intense activities. Matches are characterized by repeatedjumps for attack-hit and block, rapid changes in moving direction, and a considerable number of explosive diving digs (Magalhães, Inácio, Oliveira, Ribeiro, \& Ascensão, 2011).

The major skills which characterize the game of Beach volleyball are: serve, serve reception, set, attack, block, and dig (Hare \& Sanderson, 1997; Homberg \& Papageorgiou,

(c) Kumar, G., Shukla, A., Chhoker, A., Thapa, R. K., 2021.
1995; Kiraly \& Shewman, 1999; Stevenson \& Obstfeld, 1989). Serve, attack and block give direct score points to the team, whereas serve reception, set, and dig allows for the next technical skills (Giatsis \& Zahariadis, 2008). The game has two phases: side out and counterattack. The side out phase includes serve reception, setting, and dig \& the counterattack phase includes block, dig, set, and attack (Costa, Afonso, Brant, \& Mesquita, 2012).

Researchers have always been keen to analyze and evaluate technical and tactical aspects of the team's performances in various sports. The characteristics of the beach volleyball game have been previously studied (Hansen, 2002; Hömberg \& Papageorgiou, 1995; Papageorgiou \& Hömberg, 2004), but sports are in constant evolution and it is necessary to analyze them on a regular basis. In 2001, rules on court size and the scoring system changed, which led authors to research how this affected the game. Some studies investigated court size 

Volleyball: a Logistical Regression Approach

(Giatsis, Papadopoulou, Dimitrov, \& Likesas, 2003; Hömberg \& Papageorgiou, 1995; Kröger, 2006; Ronglan \& Grydeland, 2006) and others focused on the scoring system (Giatsis, Zetou, \& Tzetzis, 2005; Kröger, 2006; Ronglan \& Grydeland, 2006). Furthermore, some studies analyzed technical and tactical aspects such as side out and counter-attack phases, receptions, and differences between winning and losing teams (Giatsis, Lopez Martinez, \& García, 2015; Giatsis \& Tzetzis, 2003; Michalopoulou, Papadimitriou, Lignos, Taxildaris, \& Antoniou, 2005). A study conducted by Giatsis and Tzetzis (2003) postulates the different technical skills contribute to winning on different court dimensions $(8 \mathrm{x} 9 \mathrm{~m}$ and $9 \times 9 \mathrm{~m})$ in Hellenic Beach Volleyball finals. The results showed that winners have a better percentage in the attack in $8 \times 8 \mathrm{~m}$, while they had better serve reception performance in the $9 \times 9 m$ court.

Traditionally, coaching intervention has been based on subjective observations of athletes, but such observations are not only unreliable but also inaccurate (Huges \& Franks, 2010). To solve this issue, computer-aided analysis has been involved in sports performance analysis. The use of notational analysis (Castro, Souza, \& Mesquita, 2011; Marcelino, Mesquita, \& Sampaio, 2011) and computerized systems (Eom \& Schutz, 1992a, 1992b) is the most common methodology in sports performance studies, which had improved the speed, accuracy, and efficiency of data analysis. Notational analysis is the process of recording, treatment, and diagnostics of events taking place in a competition (Drust, 2010). Several studies have been conducted on the notational analysis of technical and tactical aspects of volleyball (Ciuffarella et al., 2013) and beach volleyball (Jimenez-Olmedo, PenichetTomas, Saiz-Colomina, Martinez-Carbonell, \& Jove-Tossi, 2012; Koch \& Tilp, 2009b; Pérez-Turpin et al., 2019; Tilp, Koch, Stifter, \& Ruppert, 2006). It has facilitated coaches in the analysis of movement patterns, strategy, and tactics of the individual player as well as the team's performance.

Although numerous studies have been published related to Beach volleyball (Giatsis \& Zahariadis, 2008; Koch \& Tilp, 2009a; Papadopoulou, Giatsis, Billis, Giannako, \& Bakirtzoglou, 2020; Seweryniak, Mroczek, \& Łukasik, 2013), only a few have been published regarding the factors responsible for winning and losing in Beach volleyball for men and women (Gabrio, 2021; Giatsis \& Tzetzis, 2003; Medeiros, Marcelino, Mesquita, \& Palao, 2017). As the game of beach volleyball is showing an exponential competitive growth pattern, technical skills that are key for success in this game are need to be researched and focused on so that the teams and coaches can prepare themselves accordingly. Therefore, the purpose of this study was to identify the factors which determine winning in a beach volleyball game for men as well as women using a logistical regression approach.

\section{Materials and methods}

To identify the factors which determine the winning of a beach volleyball game the matches played during the FIVB Beach Volleyball Men and Women World Championships of 2017 and 2019 were considered in this study. The study variables selected for analyses were the break point, service error, service point, reception error, attack error, attack blocked, attack point, attack point percent, block, and opponent error (Table 1).
Table 1. Description of selected skills for the analysis

\begin{tabular}{ll}
\hline Factors & Description \\
\hline Break point & $\begin{array}{l}\text { A point scored when the team is in } \\
\text { possession of service }\end{array}$
\end{tabular}

Service error

If the server hits or fails to go over the net, the serve goes out-of-bounds or the server called a foot or time violation

Service point

If the server gets a direct point from the service

Reception error

A player passes the ball, but it cannot be kept in play

Attack Error

When an attack is hit out of bounds or hit into the net leading to a four hit

Attack Blocked

The ball is blocked down by the opposition on the same side as the attacker and cannot be kept in play

Attack Point

An attack point is any ball that is sent over the net to the opponent and gets success

Attack Point Percent Attack points minus attack errors divided by total attacks

Block The block is the skill of stopping or altering an opponent's attack by players standing at the net. An offensive block aims at keeping the ball into the opponent's court, while a defensive block aims at getting the ball under control by slowing it down

Opponent Error It is the acquisition of numbers that are considered to benefit the team because it does not go through the process of the activities of the team itself. It also called 'Free Score'

\section{Subjects}

The study sample consisted of a total of 212 matches for men and 214 matches for women of the 2017 \& 2019 FIVB Men and Women Beach Volleyball World Championships held at Vienna \& Hamburg from 28 July to 6 Aug 2017 and 28 June to 7 July 2019. The matches were played by 192 teams (both men and women combined) consisting of 384 numbers (both men and women combined) of players from different nations. The data for the present study was extracted from the official website of FIVB (http://vienna2017.fivb.com/en/ schedule\#/d20170806) for 2017 for Beach Volleyball World Championship and (http://hamburg2019.fivb.com/en/ schedule\#/d20190708) for the 2019 Beach Volleyball World Championship.

\section{Statistical Analysis}

All the statistical analyses were performed with IBM SPSS (version 20.0.0). The data were analyzed using Binary Logistic Regression (Forward: LR Method) with the result of the game as the dependent variable and predictor variables as covariates. $\beta$, standard error $\beta$, Wald's $\chi^{2}$, odds ratio with $95 \%$ confidence interval were calculated. Model evaluation was conducted using the likelihood ratio test, Cox \& Snell $\left(\mathrm{R}^{2}\right)$, and Nagelkerke $\left(\mathrm{R}^{2}\right)$ tests. The goodness of fit test for the models was conducted using the Hosmer \& Lemeshow 
Table 2. Logistic Regression Analysis of beach volleyball matches for match outcomes as win or loss

\begin{tabular}{|c|c|c|c|c|c|c|c|}
\hline \multicolumn{8}{|l|}{ Men's matches } \\
\hline Predictor & $\beta$ & $\mathrm{SE} \beta$ & Wald's $\chi^{2}$ & df & $\mathbf{p}$ & $\begin{array}{c}e^{\beta} \\
\text { (odds ratio) } \\
\end{array}$ & $\begin{array}{c}\text { 95\% C.I. } \\
\left(e^{\beta}\right) \\
\end{array}$ \\
\hline Constant & -13.005 & 1.741 & 55.781 & 1 & $<0.001$ & - & - \\
\hline Break point & 0.321 & 0.60 & 28.711 & 1 & $<0.001$ & 1.378 & $1.226-1.550$ \\
\hline Service point & 0.230 & 0.066 & 12.158 & 1 & $<0.001$ & 1.259 & $1.106-1.433$ \\
\hline Reception error & -0.279 & 0.069 & 16.165 & 1 & $<0.001$ & 0.756 & $0.660-0.867$ \\
\hline Attack error & -0.176 & 0.073 & 5.646 & 1 & 0.017 & 0.839 & $0.726-0.968$ \\
\hline Attack point percentage & 0.141 & 0.024 & 34.206 & 1 & $<0.001$ & 1.151 & $1.098-1.207$ \\
\hline Block & 0.219 & 0.092 & 5.676 & 1 & 0.017 & 1.245 & $1.040-1.492$ \\
\hline Opponent error & 0.240 & 0.045 & 28.822 & 1 & $<0.001$ & 1.272 & $1.165-1.388$ \\
\hline \multicolumn{2}{|c|}{ Test } & & $x^{2}$ & df & $\mathbf{p}$ & $\mathbf{R}^{2}$ & \\
\hline \multicolumn{8}{|l|}{ Overall model evaluation } \\
\hline Likelihood ratio test & & & 324.290 & 7 & $<0.001$ & & \\
\hline Cox \& Snell & & & & & & 0.535 & \\
\hline Nagelkerke & & & & & & 0.713 & \\
\hline \multicolumn{8}{|l|}{ Goodness-of-fit test } \\
\hline Hosmer \& Lemeshow & & & 4.893 & 8 & 0.789 & & \\
\hline \multicolumn{8}{|l|}{ Women's matches } \\
\hline Predictor & $\beta$ & SE $\beta$ & Wald's $\chi^{2}$ & df & $\mathbf{p}$ & $\begin{array}{c}e^{\beta} \\
\text { (odds ratio) } \\
\end{array}$ & $\begin{array}{c}\text { 95\% C.I. } \\
\left(e^{\beta}\right) \\
\end{array}$ \\
\hline Constant & -7381 & 1.398 & 27.874 & 1 & $<0.001$ & - & - \\
\hline Break point & 0.228 & 0.49 & 21.991 & 1 & $<0.001$ & 1.256 & $1.142-1.382$ \\
\hline Reception error & -0.361 & 0.080 & 20.456 & 1 & $<0.001$ & 0.697 & $0.596-0.815$ \\
\hline Attack error & -0.310 & 0.66 & 21.913 & 1 & $<0.001$ & 0.733 & $0.644-0.835$ \\
\hline Attack blocked & -0.276 & 0.087 & 10.058 & 1 & 0.002 & 0.759 & $0.640-0.900$ \\
\hline Attack point percentage & 0.111 & 0.023 & 22.555 & 1 & $<0.001$ & 1.117 & $1.067-1.169$ \\
\hline Block & 0.197 & 0.098 & 4.039 & 1 & 0.44 & 1.217 & $1.005-1.474$ \\
\hline Opposition error & 0.214 & 0.43 & 24.484 & 1 & $<0.001$ & 1.239 & $1.138-1.349$ \\
\hline \multicolumn{3}{|c|}{ Test } & $\chi^{2}$ & df & p & $\mathbf{R}^{2}$ & \\
\hline \multicolumn{8}{|l|}{ Overall model evaluation } \\
\hline Likelihood ratio test & & & 338.938 & 7 & $<0.001$ & & \\
\hline Cox \& Snell & & & & & & 0.547 & \\
\hline Nagelkerke & & & & & & 0.729 & \\
\hline \multicolumn{8}{|l|}{ Goodness-of-fit test } \\
\hline Hosmer \& Lemeshow & & & 14.524 & 8 & 0.069 & & \\
\hline
\end{tabular}

test. In addition, observed and predicted frequencies by the regression model were also calculated with a cut-off of 0.50 . The statistical level of significance was set at $\mathrm{p} \leq 0.05$.

\section{Results}

Men

A total of 424 observations were analyzed for men and the logistic regression analysis found the following variables as significant in determining the model for winning of matches: break point, service point, reception error, attack error, attack point percentage, block, and opponent error.

Predicted logit of Winning (men) $=-13.005+0.321 \cdot($ break point $)+0.230 \cdot($ service point $)+(-0.279) \cdot($ reception error $)+$ $(-0.176) \cdot($ attack error $)+0.141 \cdot($ attack point percentage $)+$ $0.219 \cdot$ (block) $+0.240 \cdot($ opponent error $)$

The Likelihood ratio test of the model resulted in $\chi^{2}$ value of 324.29 with $\mathrm{p}<0.001$. In addition, the Cox and Snell re-
Table 3. The observed and the predicted frequencies for match results by Logistic Regression model with the cut-off of 0.50

\begin{tabular}{lrcc}
\hline \multirow{2}{*}{ Observed } & \multicolumn{2}{c}{ Predicted } & \multirow{2}{*}{ \% correct } \\
\cline { 2 - 3 } & Loss & Won & \\
\hline Men's matches & & & 85.2 \\
\hline Loss & 179 & 31 & 89.7 \\
Won & 22 & 192 & 87.5 \\
Overall \% correct & & & \\
\hline Women's matches & & & 88.1 \\
\hline Loss & 185 & 25 & 87.2 \\
Won & 28 & 190 & 87.6 \\
Overall \% correct & & & \\
\hline
\end{tabular}

sulted in $\mathrm{R}^{2}$ value of 0.535 and Nagelkerke resulted in $\mathrm{R}^{2}$ value of 0.713 . Goodness of fit test using Hosmer and Lemeshow resulted in a $\mathrm{p}$ value of 0.789 (Table 1 ). The overall correct predicted percentage using the model was found to be $87.5 \%$ (Table 2, Figure 1a). 
Table 4. Logistic Regression Analysis of league matches for match outcomes as win or loss

\begin{tabular}{|c|c|c|c|c|c|c|c|}
\hline \multicolumn{8}{|l|}{ Men's league matches } \\
\hline Predictor & $\beta$ & SE $\beta$ & Wald's $\chi^{2}$ & df & $\mathbf{p}$ & $\begin{array}{c}e^{\beta} \\
\text { (odds ratio) }\end{array}$ & $\begin{array}{c}\text { 95\% C.I. } \\
\left(e^{\beta}\right) \\
\end{array}$ \\
\hline Constant & -18.316 & 2.320 & 62.338 & 1 & $<0.001$ & - & - \\
\hline Break point & 0.309 & 0.085 & 13.176 & 1 & $<0.001$ & 1.363 & $1.153-1.611$ \\
\hline Reception error & -0.648 & 0.124 & 27.441 & 1 & $<0.001$ & 0.523 & $0.410-0.667$ \\
\hline Attack blocked & -0.087 & 0.040 & 4.652 & 1 & 0.031 & 0.916 & $0.847-0.992$ \\
\hline Attack point & 0.268 & 0.037 & 53.219 & 1 & $<0.001$ & 1.307 & $1.216-1.405$ \\
\hline Block & 0.263 & 0.112 & 5.472 & 1 & 0.019 & 1.301 & $1.044-1.622$ \\
\hline Opposition error & 0.352 & 0.062 & 32.032 & 1 & $<0.001$ & 1.422 & $1.259-1.606$ \\
\hline \multicolumn{3}{|c|}{ Test } & $\chi^{2}$ & df & $\mathbf{p}$ & $\mathbf{R}^{2}$ & \\
\hline \multicolumn{8}{|l|}{ Overall model evaluation } \\
\hline \multicolumn{3}{|l|}{ Likelihood ratio test } & 308 & 6 & $<0.001$ & & \\
\hline \multicolumn{3}{|l|}{ Cox \& Snell } & & & & 0.582 & \\
\hline \multicolumn{3}{|l|}{ Nagelkerke } & & & & 0.785 & \\
\hline \multicolumn{8}{|l|}{ Goodness-of-fit test } \\
\hline \multicolumn{3}{|l|}{ Hosmer \& Lemeshow } & 9.496 & 8 & 0.302 & & \\
\hline \multicolumn{8}{|l|}{ Women's league matches } \\
\hline Predictor & $\beta$ & SE $\beta$ & Wald's $\chi^{2}$ & df & $\mathbf{p}$ & $\begin{array}{c}e^{\beta} \\
\text { (odds ratio) }\end{array}$ & $\begin{array}{c}\text { 95\% C.I. } \\
\left(e^{\beta}\right) \\
\end{array}$ \\
\hline Constant & -7.415 & 1.479 & 25.137 & 1 & $<0.001$ & 0.001 & - \\
\hline Break point & 0.243 & 0.048 & 25.843 & 1 & $<0.001$ & 1.275 & $1.161-1.4$ \\
\hline Reception error & -0.351 & 0.087 & 16.320 & 1 & $<0.001$ & 0.704 & $0.593-835$ \\
\hline Attack error & -0.263 & 0.069 & 14.628 & 1 & $<0.001$ & 0.769 & $0.672-0.880$ \\
\hline Attack point percentage & -0.242 & 0.093 & 6.839 & 1 & 0.009 & 0.785 & $0.655-0.941$ \\
\hline \multirow{2}{*}{$\begin{array}{l}\text { Attack point } \\
\text { Opposition error }\end{array}$} & 0.113 & 0.025 & 20.089 & 1 & $<0.001$ & 1.119 & $1.066-1.176$ \\
\hline & 0.207 & 0.046 & 19.923 & 1 & $<0.001$ & 1.230 & $1.123-1.347$ \\
\hline \multicolumn{2}{|c|}{$\begin{array}{ll} & \text { Test } \\
\end{array}$} & & $\chi^{2}$ & df & $\mathbf{p}$ & $\mathbf{R}^{2}$ & \\
\hline \multicolumn{8}{|l|}{ Overall model evaluation } \\
\hline \multicolumn{2}{|l|}{ Likelihood ratio test } & & 287.509 & 6 & $<0.001$ & & \\
\hline \multicolumn{2}{|l|}{ Cox \& Snell } & & & & & 0.544 & \\
\hline \multicolumn{2}{|l|}{ Nagelkerke } & & & & & 0.726 & \\
\hline \multicolumn{8}{|l|}{ Goodness-of-fit test } \\
\hline \multicolumn{3}{|l|}{ Hosmer \& Lemeshow } & 19.542 & 8 & 0.012 & & \\
\hline
\end{tabular}

In addition, the total observations were further subgrouped into the league and knockout stages and analyzed. The following variables were found significant in determining the model for winning league matches: break point, reception error, attack blocked, attack point, block, and opposition error. Predicted logit of winning (men league round) $=-18.316+$ $0.309 \cdot($ break point $)+(-0.648) \cdot($ reception error $)+(-0.087) \cdot($ attack blocked $)+0.268 \cdot($ attack point $)+0.263 \cdot($ block $)+$ $0.352 \cdot$ (opposition error)

The Likelihood ratio test of the model resulted in a $\chi^{2}$ value of 308 with $\mathrm{p}<0.001$. In addition, the Cox and Snell resulted in an $\mathrm{R}^{2}$ value of 0.582 and Nagelkerke resulted in an $\mathrm{R}^{2}$ value of 0.785 . The goodness of fit test using Hosmer and Lemeshow resulted in a p-value of 0.302 (Table 4). The overall correct predicted percentage using the model was found to be 87.6\% (Table 5, Figure 1c).

In knockout matches following variables were found significant in determining the model: break point, reception error, attack error, and attack point.
Table 5. The observed and the predicted frequencies for league match results by Logistic Regression model with the cut-off of 0.50

\begin{tabular}{lrrl}
\hline \multirow{2}{*}{ Observed } & \multicolumn{2}{c}{ Predicted } & \multirow{2}{*}{ \% correct } \\
\cline { 2 - 3 } & Loss & Won & \\
\hline Men's matches & & & 87.7 \\
\hline Loss & 150 & 21 & 87.5 \\
Won & 22 & 154 & 87.6 \\
Overall \% correct & & & \\
\hline Women's matches & & & 88.3 \\
\hline Loss & 158 & 21 & 88.2 \\
Won & 22 & 165 & 88.3 \\
Overall \% correct & & & \\
\hline
\end{tabular}

Predicted logit of winning (men knockout round $)=-0.989+$ $0.734 \cdot($ break point $)+(-0.787) \cdot($ reception error $)+(-0.459) \cdot$ at tack error $+0.116 \cdot($ attack point $)$ 
(a)

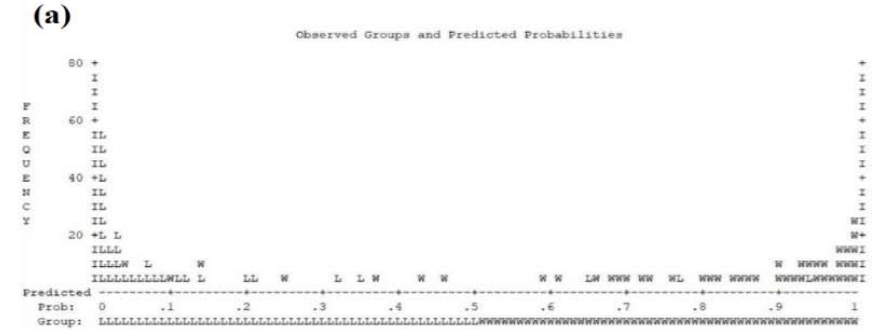

(c)

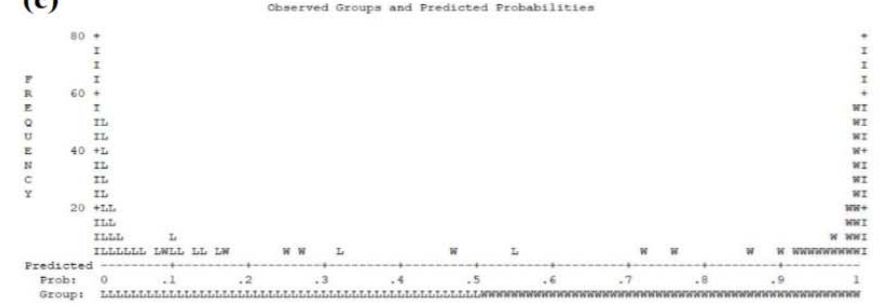

(e)

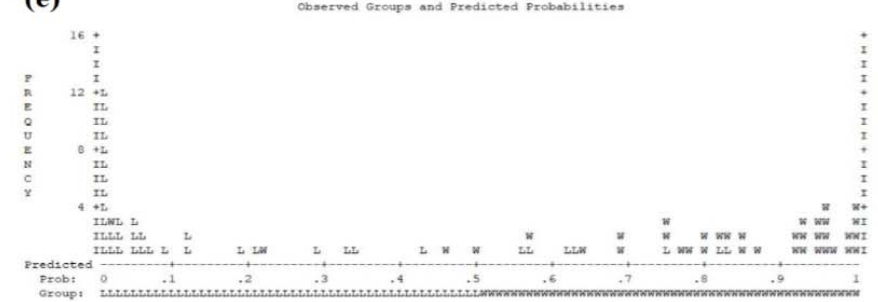

(b)

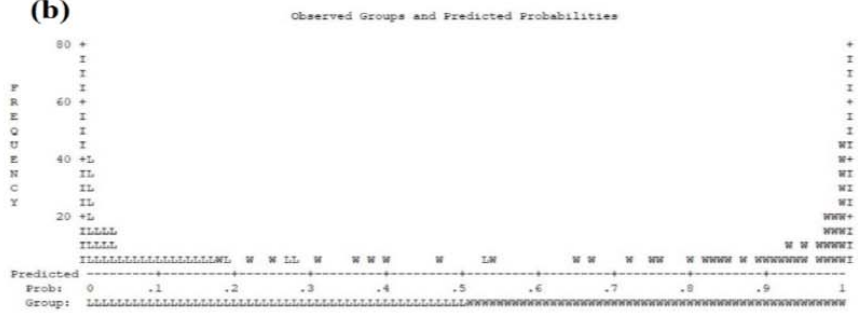

(d)

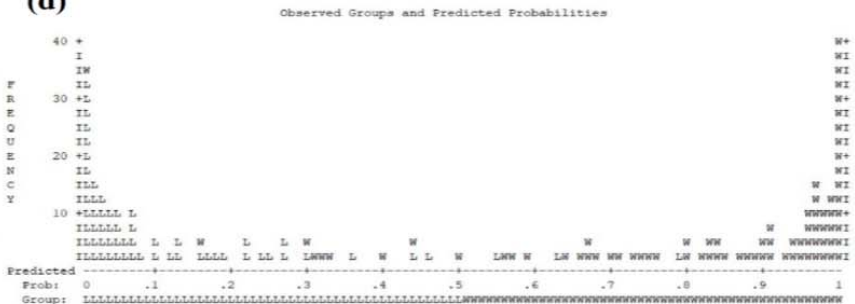

(f)

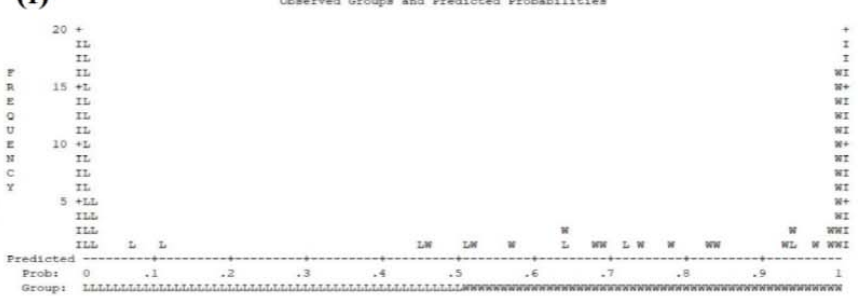

Fig. 1. Predicted probability for membership for winning a match in beach volleyball using the model. (a) men's overall matches, (b) women's overall matches, (c) men's league matches, (d) women's league matches, (e) men's knockout matches, and (f) women's knockout

matches. Note: The cut-off value is 0.50 . Symbols 'L' represents Lost and 'W' represents Win and each symbol represents 5 cases.

The Likelihood ratio test of the model resulted in a $\chi^{2}$ value of 59.498 with $p<0.001$. In addition, the Cox and Snell resulted in an $\mathrm{R}^{2}$ value of 0.538 and Nagelkerke resulted in an $\mathrm{R}^{2}$ value of 0.718 . The goodness of fit test using Hosmer and Lemeshow resulted in a p-value of 0.122 (Table 6). The overall correct predicted percentage using the model was found to be 85.7\% (Table 7, Figure 1e).

\section{Women}

A total of 428 observations were analyzed for women and the logistic regression analysis found the following factors as significant in determining the model for wining of the match: break point, reception error, attack error, attack blocked, attack point percent, block, and opponent error.

Predicted logit of winning (women $)=-7381+0.228$ (break point $)+(-0.361) \cdot($ reception error $)+(-0.310) \cdot($ attack error $)$ $+(-0.276) \cdot($ attack blocked $)+0.111 \cdot($ attack point percent $)+$ $0.197 \cdot($ block $)+0.214 \cdot($ opposition error)

The Likelihood ratio test of the model resulted in a $\chi^{2}$ value of 338.938 with $p<0.001$. In addition, the Cox and Snell resulted in an $\mathrm{R}^{2}$ value of 0.547 and Nagelkerke resulted in an $\mathrm{R}^{2}$ value of 0.729 . The goodness of fit test using Hosmer and Lemeshow resulted in a p-value of 0.069 (Table 2). The overall correct predicted percentage using the model was found to be $87.6 \%$ (Table 3, Figure $1 \mathrm{~b}$ ).

In addition, the total observations were further subgrouped into the league and knockout stages and analyzed. The following variables were found significant in determining the model for winning league matches: break point, re- ception error, attack error, attack point percentage, attack point, and opposition error.

Predicted logit of winning (women league matches) $=-7.415+$ $0.243 \cdot($ break point $)+(-0.351) \cdot($ reception error $)+(-0.263) \cdot($ at tack error $)+(-0.242) \cdot($ attack point percentage $)+0.113 \cdot($ attack point $)+0.207 \cdot($ opposition error $)$

The Likelihood ratio test of the model resulted in a $\chi^{2}$ value of 287.509 with $\mathrm{p}<0.001$. In addition, the Cox and Snell resulted in an $\mathrm{R}^{2}$ value of 0.544 and Nagelkerke resulted in an $\mathrm{R}^{2}$ value of 0.726 . The goodness of fit test using Hosmer and Lemeshow resulted in a p-value of 0.012 (Table 4). The overall correct predicted percentage using the model was found to be $88.3 \%$ (Table 5, Figure 1d).

In knockout matches following variables were found significant in determining the model: break point, service point, reception error, attack error, attack blocked, attack point, and opposition error.

Predicted logit of winning (women knockout matches $)=-18.564$ $+1.846 \cdot($ break point $)+(-1.537) \cdot($ service point $)+(-1.167) \cdot($ re ception error $)+(-1.011) \cdot($ attack error $)+(-0.542) \cdot$ attack blocked $+0.473 \cdot($ attack point $)+0.346 \cdot($ opposition error $)$

The Likelihood ratio test of the model resulted in a $\chi^{2}$ value of 63.929 with $p<0.001$. In addition, the Cox and Snell resulted in an $R^{2}$ value of 0.643 and Nagelkerke resulted in an $\mathrm{R}^{2}$ value of 0.858 . The goodness of fit test using Hosmer and Lemeshow resulted in a p-value of 1 (Table 6). The overall correct predicted percentage using the model was found to be $91.9 \%$ (Table 7, Figure 1f). 
Table 6. Logistic Regression Analysis of knockout matches for match outcomes as win or loss

Men's knockout matches

\begin{tabular}{|c|c|c|c|c|c|c|c|}
\hline Predictor & $\beta$ & SE $\beta$ & Wald's $\chi^{2}$ & df & $\mathbf{p}$ & $\begin{array}{c}\mathrm{e}^{\beta} \\
\text { (odds ratio) }\end{array}$ & $\begin{array}{c}\text { 95\% C.I. } \\
\left(e^{\beta}\right)\end{array}$ \\
\hline Constant & -0.989 & 4.169 & 5.623 & 1 & 0.018 & - & \\
\hline Break point & 0.734 & 0.196 & 14.048 & 1 & $<0.001$ & 2.084 & $1.420-3.060$ \\
\hline Reception error & -0.787 & 0.265 & 8.855 & 1 & 0.003 & 0.455 & $0.271-0.764$ \\
\hline Attack error & -0.459 & 0.225 & 4.152 & 1 & 0.042 & 0.632 & $0.406-0.983$ \\
\hline Attack point & 0.116 & 0.063 & 3.402 & 1 & 0.065 & 1.123 & 0.993-1.270 \\
\hline \multicolumn{3}{|c|}{ Test } & $x^{2}$ & df & $\mathrm{p}$ & $\mathbf{R}^{2}$ & \\
\hline \multicolumn{8}{|c|}{ Overall model evaluation } \\
\hline \multicolumn{3}{|l|}{ Likelihood ratio test } & 59.498 & 4 & $<0.001$ & & \\
\hline \multicolumn{3}{|l|}{ Cox \& Snell } & & & & 0.538 & \\
\hline \multicolumn{3}{|l|}{ Nagelkerke } & & & & 0.718 & \\
\hline \multicolumn{8}{|l|}{ Goodness-of-fit test } \\
\hline \multicolumn{3}{|l|}{ Hosmer \& Lemeshow } & 12.705 & 8 & 0.122 & & \\
\hline \multicolumn{8}{|c|}{ Women's Knockout matches } \\
\hline Predictor & $\beta$ & SE $\beta$ & Wald's $\chi^{2}$ & df & $\mathbf{p}$ & $\begin{array}{c}e^{\beta} \\
\text { (odds ratio) }\end{array}$ & $\begin{array}{c}95 \% \text { C.I. } \\
\left(e^{\beta}\right) \\
\end{array}$ \\
\hline Constant & -18.564 & 8.671 & 4.583 & 1 & 0.032 & - & \\
\hline Break point & 1.846 & 0.765 & 5.821 & 1 & 0.016 & 6.333 & $1.414-28.371$ \\
\hline Service point & -1.537 & 0.719 & 4.565 & 1 & 0.033 & 0.215 & $0.053-0.881$ \\
\hline Reception error & -1.167 & 0.581 & 4.040 & 1 & 0.044 & 0.311 & $0.1-0.971$ \\
\hline Attack error & -1.011 & 0.497 & 4.147 & 1 & 0.042 & 0.364 & $0.137-0.963$ \\
\hline Attack blocked & -0.542 & 0.277 & 3.833 & 1 & 0.050 & 0.582 & $0.338-1.001$ \\
\hline Attack point & 0.473 & 0.227 & 4.335 & 1 & 0.037 & 1.605 & $1.028-2.504$ \\
\hline \multirow[t]{2}{*}{ Opposition error } & 0.346 & 0.152 & 5.208 & 1 & 0.022 & 1.414 & $1.050-1.903$ \\
\hline & & & $x^{2}$ & df & p & $\mathbf{R}^{2}$ & \\
\hline \multicolumn{8}{|c|}{ Overall model evaluation } \\
\hline \multicolumn{2}{|l|}{ Likelihood ratio test } & & 63.929 & 7 & $<0.001$ & & \\
\hline \multicolumn{2}{|l|}{ Cox \& Snell } & & & & & 0.643 & \\
\hline \multicolumn{2}{|l|}{ Nagelkerke } & & & & & 0.858 & \\
\hline \multicolumn{8}{|l|}{ Goodness-of-fit test } \\
\hline \multicolumn{2}{|l|}{$\underline{\text { Hosmer \& Lemeshow }}$} & & 0.280 & 8 & 1 & & \\
\hline
\end{tabular}

\section{Discussion}

The purpose of this study was to identify important skill related factors that were significantly responsible for winning in the beach volleyball championships using a logistic regression approach. A forward step method indicated seven factors (out of ten) were related to winning in men's competition. In addition, five factors were positively related (break point, service point, attack point percentage, block, opponent error) while two factors (reception error and attack error) were negatively related to winning. In the case of women's competition, a forward step method indicated seven factors (out of ten) were related to winning. In addition, four factors (break point, attack point percentage, block, and opposition error) were positively related while three factors (reception error, attack error, and attacked blocked) were negatively related to winning.

Further classification of the observations into the league and knockout rounds resulted in an indication of six factors (out of ten) related to winning in the league round, while four factors (out of ten) were related to winning in knock out round in men's competition. In the case of women's competition, six factors (out of ten) were related to winning in the league round, and seven factors (out of ten) were related to winning in the knockout round.
Table 7. The observed and the predicted frequencies for knockout match results by Logistic Regression model with the cut-off of 0.50

\begin{tabular}{lrcc}
\hline \multirow{2}{*}{ Observed } & \multicolumn{2}{c}{ Predicted } & \multirow{2}{*}{ \% correct } \\
\cline { 2 - 3 } & Loss & Won & \\
\hline Men's matches & & & \\
\hline Loss & 32 & 7 & 82.1 \\
Won & 4 & 34 & 89.5 \\
Overall \% correct & & & 85.7 \\
\hline Women's matches & & & \\
\hline Loss & 27 & 4 & 87.1 \\
Won & 1 & 30 & 96.8 \\
Overall \% correct & & & 91.9 \\
\hline
\end{tabular}

Our study suggests few factors to be significantly responsible for winning in beach volleyball competition, such as break point, service point, attack point percentage, block, opponent's error, reception error, attack error, and attack blocked. Break points include one's own service aces, counterattack points, and a number of winning blocks, and the opponent's errors, although these factors did not explain the 
outcomes of matches by themselves in our model. In this competition, the number of points obtained in the break point phase was the factor that made the greatest contribution to the final outcomes. This factor is completely related to the performance of the opponent's reception and the opponent's attack (Peña, Rodríguez-Guerra, Buscà, \& Serra, 2013). The service point was also found to be an important factor in determining success in both men and women beach volleyball competition. A previous similar study conducted on volleyball supports our findings (Silva, Lacerda, \& João, 2014). The teams are evenly balanced at the world championship level, and when the match gets close to end the serve skill may be associated with victory. The service is the only moment of the game when the players have $100 \%$ control over the ball and the way events unfold. The players need to choose the type of service, the force, and the area of the opponent's court to which the service will be directed (Martinez \& Abreu, 2003). Service is an opportunity to create the maximum number of problems for the receiving opponent and also score a direct point if possible. Thus, the service is the team's one of the most pre-eminent offensive weapons, causing a range of problems for the receiving team, restricting, forestalling, and even eliminating the possibility of an effective attack on the part of the opponents. A study by Quiroga et al. (2012) analyzed 1300 services and divided them into four components. The components with the greatest influence were related to the type of service used, highlighting the importance of the technical execution and the characteristics of the chosen action, as well as the speed imparted to the service ball. It was found that the players tried to execute a service that secures a direct point or that at least impedes the opposing team from mounting an attack, and to this end, they aim for a service that is accurate, difficult to receive, and very often powerful. The points gained through attack were also found to be the most important skill in volleyball (Lobietti, Di Michele, \& Merni, 2006). A previous study also found a significant association between the attack efficiency and the set outcome (Monteiro, Mesquita, \& Marcelino, 2009). The reason may be that the teams that win the sets make fewer errors and have higher efficiency in the counter attack. In the similar vein, the attack error and attacks blocked also plays a significant role in winning a match in beach volleyball.

Blocking is an important skill in any format of volleyball to stop the attack at the net and blocking successfully is one of the crucial features of winning in volleyball (Lobietti, 2009). Previous studies (Lobietti et al., 2006) also investigated the importance of block to win the game using cluster analysis in the Italian volleyball professional league and results suggest the block to be the second most important skill after the attack. The points gained using block were also found to be highly correlated to the final ranking (Lobietti et al., 2006). The nature of every sport is such that teams try to find the weaker link in the opponent team to gain benefits. Team tactics are always such that the opponents are forced to commit an error. Our study findings suggest that the opponent's error is linked to winning in elite beach volleyball competition. Previous studies suggest the quality of reception as an important factor in winning a volleyball match (Paulo, Zaal, Fonseca, \& Araújo, 2016; Peña et al., 2013; Silva et al., 2014). During the reception, many task-related functional constraints might influence the behavior of the receiver (Barsingerhorn, Zaal, De Poel, \& Pepping, 2013). The jump- float serve takes about 1 second to reach the receiver, who needs about 300 milliseconds to initiate his first movement (Benerink, Bootsma, \& Zaal, 2015). The receiver's position and movement have effects on how to pass a serve (Paulo et al., 2016), and a player not able to flexibly adapt to varying constraints results in loosing points.

Differences between winning and losing teams have been of particular interest to researchers, and previous studies indicate that attack efficiency and error percentage were the primary factors in winning a match (Giatsis \& Zahariadis, 2008; Michalopoulou et al., 2005). This could explain why there is more offensive than defensive movements and vertical advance movements in professional women's beach volleyball (Pérez-Turpin, Cortell-Tormo, Suárez-Llorca, Chinchilla-Mira, \& Cejuela-Anta, 2009).

In addition to this, there was some significant reflection in our findings when the observations were further divided based on league matches or knockout matches. In men's competition, six factors were found to significantly affect the winning of matches in the league round, whereas only four factors were found significant in knockout rounds. One reason for this finding may be attributed to the fact that only the best teams qualify to the knockout rounds through the league matches. With the best teams playing in the knockout stages, it becomes evident that only a few factors will be contributing to the winning. Giatsis and Zahariadis (2008) could observe that 2:0 winning teams on an international level (FIVB) have superior skills in almost all techniques, especially in avoiding attack errors. During close games (2:1 wins) only the amount of points discriminated winners from losers. Michalopoulou et al. (2005) identified the effectiveness of attack and serve as key predictors for winning teams on the Greek national level.

Similarly, in women's competition, seven factors were found contributing to winning in league rounds, while six factors were contributing to winning in knockout rounds. Although not similar to men, women teams also showed one factor less contributing during the knockout rounds than league rounds. The differences in the factors between men and women for winning league or knockout may be explained by the fact that males are significantly different from females with respect to physical, physiological, psychological aspects (Lewis, Kamon, \& Hodgson, 1986). Previous studies observed differences in the type of techniques used between gender (Koch \& Tilp, 2009b; Yiannis, 2008). Women's beach volleyball is considered to employ more effective defense strategies, due in part to their lower levels of strength, speed, and jump height and causes their attacks to not to be as dynamic as in men's volleyball (Macial et al., 2009). A previous study also observed significant sex differences in frequencies of techniques applied for service, reception, setting, attack, and block and defense, which may indicate differences in movement pattern between men and women (Koch \& Tilp, 2009b).

\section{Conclusion}

Our study concludes that there is a significant association of important factors with respect to winning a match in an elite beach volleyball championship. The coaches and players can take note of the important factors responsible for winning in the elite beach volleyball championship, with different factors playing important role in men and women 
competition during league and knockout rounds as well. This may also help the coaches design their training periodization considering the factors that are important for their team.

\section{References}

Magalhães, J., Inácio, M., Oliveira, E., Ribeiro, J. C., \& Ascensão, A. (2011). Physiological and neuromuscular impact of beach-volleyball with reference to fatigue and recovery. Journal of Sports Medicine and Physical Fitness, 51(1), 66-73.

Hare, D., \& Sanderson, D. (1997). A guide to winning doubles volleyball. Corona Del Mar: Volleyball International Publication.

Homberg, S., \& Papageorgiou, A. (1995). Handbook for beach volleyball. Aachen: Meyer and Meyer Verlag.

Kiraly, K., \& Shewman, B. (1999). Beach Volleyball. Champaign, IL: Human Kinetics.

Stevenson, J., \& Obstfeld, R. (1989). Hot Sand: The Beach Volleyball handbook. Irvine, CA: Windmill Press.

Giatsis, G., Lopez Martinez, A. B., \& García, G. M. G. (2015). The efficacy of the attack and block in game phases on male FIVB and CEV beach volleyball. Journal of Human Sport and Exercise, 10(2), 537-549. https://doi.org/10.14198/jhse.2015.102.01

Costa, G., Afonso, J., Brant, E., \& Mesquita, I. (2012). Differences in game patterns between male and female youth volleyball. Kinesiology, 44(1), 60-66.

Hansen, G. (2002). Systematische Spielbeobachtung zur "Weltstandsanaylse" am Beispiel Beachvolleyball. [Systematic game analysis in beach volleyball. In German.]. In K. Ferger, N. Gissel, \& J. Schwier (Eds.), Sportspiele erleben, Vermitteln, Trainieren (pp. 275-282). Hamburg: Czwalina.

Hömberg, S., \& Papageorgiou, A. (1994). Handbuch für Beachvolleyball. Technik, Taktik, Training. [Handbook for beach volleyball. Techniques, tactics, training. In German.]. Aachen: Meyer \& Meyer.

Papageorgiou, A., \& Hömberg, S. (2004). Vergleichende Strukturanalyse des Sportspiels Beachvolleyball. [Comparative game analysis in beach volleyball. In German.] In K. Zentgraf \& K. Langolf (Eds.), Volleyball Europaweit (pp. 33-46). Hamburg: Czwalima.

Giatsis, G., Papadopoulou, S., Dimitrov, P., \& Likesas, G. (2003). Comparison of beach volleyball team performance pearameters after a reduction in the court's dimensions. International Journal of Volleyball Research, 6(1), 2-5.

Kröger, C. (2006). Auswirkungen von Regeländerungen im Beachvolleyball. [Effects of rule changes in beach volleyball. In German.] In M. Raab, A. Arnold, K. Gärtner, J. Köppen, C. Lempertz, N. Tielemann, \& H. Zastrow (Eds.), Zukunft der Sportspiele: fördern, fordern, forschen (pp. 136-139). Flensburg: Flensburg University Press.

Ronglan, L. T., \& Grydeland, J. (2006). The effects of changing the rules and reducing the court dimension on the relative strengths between game actions in top international beach volleyball. International Journal of Performance Analysis in Sport, 6(1), 1-12.

https://doi.org/10.1080/24748668.2006.11868351
Giatsis, G., Zetou, E., \& Tzetzis, G. (2005). The effect of rule changes for the scoring system on the duration of the beach volleyball game. Journal of Human Movement Studies, 48(1), 15-23.

Giatsis, G., \& Tzetzis, G. (2003). Comparison of performance for winning and losing beach volleyball teams on different court dimensions. International Journal of Performance Analysis in Sport, 3(1), 65-74.

https://doi.org/10.1080/24748668.2003.11868276

Michalopoulou, M., Papadimitriou, K., Lignos, N., Taxildaris, K., \& Antoniou, P. (2005). Computer analysis of the technical and tactical effectiveness in Greek Beach Volleyball. International Journal of Performance Analysis in Sport, 5(1), 41-50. https://doi.org/10.1080/24748668.2005.11868314

Huges, M., \& Franks, I. M. (2010). Notational Analysis of Sport (Second ed.). London: Routledge Taylor and Francis Group.

Castro, J., Souza, A., \& Mesquita, I. (2011). Attack efficacy in volleyball: elite male teams. Perceptual and Motor Skills, 113(2), 395-408. https://doi.org/10.2466/05.25.Pms.113.5.395-408

Marcelino, R., Mesquita, I., \& Sampaio, J. (2011). Effects of quality of opposition and match status on technical and tactical performances in elite volleyball. Journal of Sports Sciences, 29(7), 733-741. https://doi.org/10.1080/02640414.2011.552516

Eom, H. J., \& Schutz, R. W. (1992a). Statistical analyses of volleyball team performance. Research Quarterly for Exercise and Sport, 63(1), 11-18. https://doi.org/10.1080/02701367.1992.10607551

Eom, H. J., \& Schutz, R. W. (1992b). Transition play in team performance of volleyball: a log-linear analysis. Research Quarterly for Exercise and Sport, 63(3), 261-269. https://doi.org/10.1080/02701367.1992.10608741

Drust, B. (2010). Performance analysis research: Meeting the challenge. Journal of Sports Sciences, 28(9), 921-922. https://doi.org/10.1080/02640411003740769

Ciuffarella, A., Russo, L., Masedu, F., Valenti, M., Izzo, R. E., \& De Angelis, M. (2013). Notational Analysis of the Volleyball Serve. Timisoara Physical Education and Rehabilitation Journal, 6(11), 29-35. https://doi.org/10.2478/tperj-2013-0013

Jimenez-Olmedo, J., Penichet-Tomas, A., Saiz-Colomina, S., Martinez-Carbonell, J., \& Jove-Tossi, M. (2012). Serve analysis of professional players in beach volleyball. Journal of Human Sport and Exercise, 7(3), 706-713. https://doi.org/10.4100/jhse.2012.73.10

Koch, C., \& Tilp, M. (2009b). Beach volleyball techniques and tactices: a comparison of male and female playing characteristics. Kinesiology, 41(1), 52-59.

Pérez-Turpin, J., Campos-Gutiérrez, L. M., Elvira-Aranda, C., Gomis-Gomis, M. J., Suárez-Llorca, C., \& AndreuCabrera, E. (2019). Performance Indicators in Young Elite Beach Volleyball Players. Frontiers in Psychology, 10(2712). https://doi.org/10.3389/fpsyg.2019.02712

Tilp, M., Koch, C., Stifter, S., \& Ruppert, S. G. (2006). Digital game analysis in beach volleyball. International Journal of Performance Analysis in Sport, 6(1), 140-148.

https://doi.org/10.1080/24748668.2006.11868362 
Giatsis, G., \& Zahariadis, P. (2008). Statistical Analysis of Men's FIVB Beach Volleyball Team Performance. International Journal of Performance Analysis in Sport, 8(1), 31-43. https://doi.org/10.1080/24748668.2008.11868420

Koch, C., \& Tilp, M. (2009a). Analysis of beach volleyball action sequences of female top athletes. Journal of Human Sport and Exercise, 4(3), 272-283. https://doi.org/10.4100/jhse.2009.43.09

Papadopoulou, S. D., Giatsis, G., Billis, E., Giannako, A., \& Bakirtzoglou, P. (2020). Comparative analysis of the techical-tactical skills of elite male beach volleyball teams. Sport Science, 13(1), 59-66.

Seweryniak, T., Mroczek, D., \& Łukasik, Ł. (2013). Analysis and evaluation of defensive team strategies in women's beach volleyball - an efficiency-based approach. Human Movement, 14(1), 48-55. https://doi.org/10.2478/v10038-012-0047-9

Gabrio, A. (2021). Bayesian hierarchical models for the prediction of volleyball results. Journal of Applied Statistics, 48(2), 301-321. https://doi.org/10.1080/02664763.2020.1723506

Medeiros, A. I. A., Marcelino, R., Mesquita, I. M., \& Palao, J. M. (2017). Performance differences between winning and losing under-19, under-21 and senior teams in men's beach volleyball. International Journal of Performance Analysis in Sport, 17(1-2), 96-108.

https://doi.org/10.1080/24748668.2017.1304029

Peña, J., Rodríguez-Guerra, J., Buscà, B., \& Serra, N. (2013). Which skills and factors better predict winning and losing in high-level men's volleyball? Journal of Strength and Conditioning Research, 27(9), 2487-2493. https://doi.org/10.1519/JSC.0b013e31827f4dbe

Silva, M., Lacerda, D., \& João, P. V. (2014). Game-Related Volleyball Skills that Influence Victory. Journal of Human Kinetics, 41, 173-179. https://doi.org/10.2478/hukin-2014-0045

Martinez, N., \& Abreu, P. P. (2003). Algunas características del saque desde el voleibol tradicional hasta el rally point [Characterisation of the Main Playing Variables Affecting the Service in High-Level Women's Volleyball]. Readings: Physical Education and Sports.

Quiroga, M. E., Rodriguez-Ruiz, D., Sarmiento, S., Muchaga, L. F., Da Silva Grigoletto, M., \& García-Manso, J. M. (2012). Characterisation of the Main Playing Variables Affecting the Service in High-Level Women's Volleyball. Journal of Quantitative Analysis in Sports, 8(1). https://doi.org/10.1515/1559-0410.1348
Lobietti, R., Di Michele, R., \& Merni, F. (2006, 24-28 August). Relationships between performance parameters and final ranking in professional volleyball. Paper presented at the World Congress of the Society of Performance Analysis in Sport, Szombathely

Monteiro, R., Mesquita, I., \& Marcelino, R. (2009). Relationship between the set outcome and the dig and attack efficacy in elite male Volleyball game. International Journal of Performance Analysis in Sport, 9(3), 294-305. https://doi.org/10.1080/24748668.2009.11868486

Lobietti, R. (2009). A review of blocking in volleyball: From the notational analysis to biomechanics. Journal of Human Sport and Exercise, 4(2), 93-99. https://doi.org/10.4100/jhse.2009.42.03

Paulo, A., Zaal, F. T., Fonseca, S., \& Araújo, D. (2016). Predicting Volleyball Serve-Reception. Frontiers in Psychology, 7, 1694. https://doi.org/10.3389/fpsyg.2016.01694

Barsingerhorn, A. D., Zaal, F. T. J. M., De Poel, H. J., \& Pepping, G. (2013). Shaping decisions in volleyball. An ecological approach to decision-making in volleyball passing. International Journal of Sport Psychology, 44(3), 197-214. https://doi.org/10.7352/IJSP.2013.44.197

Benerink, N. H., Bootsma, R. J., \& Zaal, F. T. (2015). Different temporal bases for body and arm movements in volleyball serve reception. Scandinavian Journal of Medicine in Science and Sports, 25(5), 603-609. https://doi.org/10.1111/sms.12384

Pérez-Turpin, J., Cortell-Tormo, J., Suárez-Llorca, C., Chinchilla-Mira, J., \& Cejuela-Anta, R. (2009). Gross movement patterns in elite female beach volleyball. Kinesiology, 41(2), 212-219.

Lewis, D. A., Kamon, E., \& Hodgson, J. L. (1986). Physiological differences between genders. Implications for sports conditioning. Sports Medicine, 3(5), 357-369. https://doi.org/10.2165/00007256-198603050-00005

Yiannis, L. (2008). Comparison of the basic characteristics of men's and women's beach volley from the Athens 2004 Olympics. International Journal of Performance Analysis in Sport, 8(3), 130-137. https://doi.org/10.1080/24748668.2008.11868454

Macial, R. N., Morales, A. P., Barcelos, J. L., Nunes, W. J., Azevedo, M. M. A., \& Silva, V. F. (2009). Relation between reaction time and specific function in volleyball players. Fitness and Performance Journal, 8(6), 395-399. 


\title{
ІДЕНТИФІКАЦІЯ ЧИННИКІВ, ЩО ВИЗНАЧАЮТЬ ПЕРЕМОГУ У ПЛЯЖНОМУ ВОЛЕЙБОЛІ СЕРЕД ЧОЛОВІКІВ ТА ЖІНОК: ЛОГІСТИЧНИЙ РЕГРЕСІЙНИЙ ПІДХІД
}

\author{
Гопал Кумар ${ }^{1 \mathrm{ABCD}}$, Аншуман Шукла ${ }^{2 \mathrm{AB}}$, Аміт Чокер ${ }^{2 \mathrm{AB}}$, Рохіт Кумар Тапа ${ }^{1 \mathrm{ACD}}$ \\ ${ }^{1}$ Національний інститут фізичного виховання імені Лакшмі Бай \\ ${ }^{2}$ Інститут фізичного виховання та спорту імені Індіри Ганді \\ Авторський вклад: А - дизайн дослідження; В - збір даних; C - статаналіз; D - підготовка рукопису; Е - збір коштів \\ Реферат. Стаття: 10 с., 1 рис., 7 табл., 47 джерел.
}

\begin{abstract}
Метою дослідження було ідентифікувати чинники, що визначають перемогу в чемпіонаті з пляжного волейболу серед чоловіків та жінок.

Матеріали і методи. Вибірка дослідження складалася із 212 поєдинків для чоловіків та 214 поєдинків для жінок на чемпіонаті світу з пляжного волейболу FIVB для чоловіків та жінок 2017 та 2019 років, що відбувся у Відні та Гамбурзі з 28 липня по 6 серпня 2017 року та з 28 червня по 7 липня 2019 року. Матчі зіграли 192 команди (як чоловіки, так і жінки разом), що складалися з 384 номерів (як чоловіків, так і жінок разом) гравців з різних країн. Дані аналізували за допомогою бінарної логістичної регресії (прямий: метод LR) 3 результатом гри як залежною змінною та змінними предиктора як коваріатами. Розраховували $\beta$, стандартну похибку $\beta, \chi^{2}$ Вальда, коефіцієнт шансів із 95\% довірчим інтервалом. Оцінка моделі проводилася за допомогою тесту коефіцієнта ймовірності, тестів Кокса і Снелла $\left(\mathrm{R}^{2}\right)$ та На-
\end{abstract}

гелькерке $\left(\mathrm{R}^{2}\right)$. Тест на придатність моделей проводився за допомогою тесту Хосмера та Лемешоу.

Результати. Аналіз показав, що сім чинників були пов'язані з перемогою у змаганнях серед чоловіків та жінок. У ході турів ліги шість чинників у чоловічих та сім чинників у жіночих змаганнях були пов'язані з перемогою. Крім того, у плей-оф таких чинників було чотири у чоловічих та шість у жіночих змаганнях.

Висновки. Дослідження показує, що існує суттєва асоціація важливих чинників щодо перемоги в матчах елітного чемпіонату з пляжного волейболу. Тренери та гравці можуть взяти до уваги важливі чинники, що відповідають за перемогу в елітному чемпіонаті з пляжного волейболу, при цьому різні чинники так само відіграють важливу роль у змаганнях чоловіків та жінок під час плей-оф раундів Ліги.

Ключові слова: нотаційний аналіз, шанси, FIVB, прогнозування, чемпіонат світу, майстерність.

\section{Information about the authors:}

Kumar, Gopal: gopalk.kumar8@gmail.com; https://orcid.org/0000-0002-4764-3690; Department of Exercise Physiology, Lakshmibai National Institute of Physical Education, Gwalior, 474002, India.

Shukla, Anshuman: sanshuman151@gmail.com; https://orcid.org/0000-0002-5781-5687; Department of Physical Education, Indira Gandhi Institute of Physical Education and Sports Sciences, New Delhi, 110018, India.

Chhoker, Amit: amitchhoker17@gmail.com; https://orcid.org/0000-0002-9392-4813; Department of Physical Education, Indira Gandhi Institute of Physical Education and Sports Sciences, New Delhi, 110018, India.

Thapa, Rohit Kumar: rohitthapa04@gmail.com; https://orcid.org/0000-0002-1258-9065; Department of Sports Biomechanics, Lakshmibai National Institute of Physical Education, Gwalior, 474002, India.

Cite this article as: Kumar, G., Shukla, A., Chhoker, A., \& Thapa, R. K. (2021). Identification of Factors Determining Winning in Men's and Women's Beach Volleyball: a Logistical Regression Approach. Teoriâ ta Metodika Fizičnogo Vihovannâ, 21(1), 26-35. https://doi.org/10.17309/tmfv.2021.1.04

Received: 14.01.2021. Accepted: 20.03.2021. Published: 25.03.2021

This work is licensed under a Creative Commons Attribution 4.0 International License (http://creativecommons.org/licenses/by/4.0). 